\title{
Emerging Issues and Future Prospects in the Management of Transnational Education
}

\author{
Joseph Bosire ${ }^{1} \&$ Catherine Amimo ${ }^{2}$ \\ ${ }^{1}$ Associate Professor of Education (Curriculum Studies), School of Education, Department of Curriculum and \\ Education Management, Jaramogi Oginga Odinga University of Science and Technology, Kenya \\ ${ }^{2}$ Faculty of Education, University of East Africa, Baraton, Kenya \\ Correspondence: Joseph Bosire, Associate Professor of Education (Curriculum Studies), School of Education, \\ Department of Curriculum and Education Management, Jaramogi Oginga Odinga University of Science and \\ Technology, Kenya
}

Received: July 14, 2017

Accepted: August 31, 2017

Online Published: October 23, 2017

doi:10.5430/ijhe.v6n5p143

URL: https://doi.org/10.5430/ijhe.v6n5p143

\begin{abstract}
Transnational Education has gained momentum under the auspices of the General Agreement on Trade in Services administered by World Trade Organizations which have provided for successful marketing of higher education across borders. This paper reviews past research, discussions and analyses on the topic on a global perspective. The objectives are to establish the rationale for transnational education, emerging issues over the providers, mode of supply, the potential of the market and issues on curriculum and pedagogy. Past research reveals that transnational education is anchored on economic, political, cultural and educational rationales. The global market for transnational education is asymmetrical where some nations are exporters (UK, US, Australia), and others importers (Africa, Latin America and Central Asia). The modes of provision include cross-border supply, commercial presence and presence of natural persons. The potential of the market is growing - commercial presence being dominant. The emerging issues include competition, differences in pedagogical practices, loss of nations and learner autonomy, control and self-respect of higher education, confusions on qualifications and transfer of academic credits, escalated costs, commercialization of knowledge as a commodity, dominant language (largely English) used as a medium of communication, and de-contextualization of the national curriculum. Quality assurance and accreditation are also at stake since the national/states capacity for regulating the supply of transnational education is limited. Though discussions on transnational education are on-going, stakeholders need to work with governments, non-governmental organizations, Higher Education Institutions and regulators to improve the future of transnational education, including developing an acceptable code of conduct.
\end{abstract}

Keywords: Transnational education, transactional theory, Cross-border education, Global curriculum, Virtual universities, Globalization, Higher education.

\section{Introduction}

The World Trade Organization (WTO), through the General Agreement on Trade and Services (GATS), acknowledges education as one of the 12 services for trade across nations. Transnational Education (TNE) is offered under this provision. According to UNESCO, TNE refers to all types of higher education study programmes, or sets of courses of study or educational services in which the learner can study in a foreign institution without leaving the home country. Such programmes or institutions may belong to the education system of a state different from the state in which it operates or may operate independently of any national education system (UNESCO, 2013; 2014). As a developing mode of higher education, the justification for TNE is unclear- just as its trends in terms of mode of supply, providers, and potential. Its' different modes of supply is terminologically and conceptually unclear, besides the emerging issues over its management. This paper explores these issues with a view of finding suggestions for effective management of Trans National Education systems. Specifically, the following questions guide this paper:-

1. What is the rationale and what are the trends in transnational education in terms of mode of supply, providers, and the potential of the market?

2. What are the emerging issues in the management of transnational education? 
3. How can existing national and international quality assurance systems and procedures address the quality of programs offered by transnational education providers?

\section{The Rationale and Trends in Transnational Education (TNE)}

In spite of evidence of its growth in many developing countries, research reveals that the rationale for offering transnational education is not fully understood by countries that would potentially benefit from its provision. Such lack of awareness is revealed in the fact that many host countries have very scarce data on the operations of transnational education providers within their boarders. This section discusses the rationale and trends in transnational education.

\subsection{Rationale for Transnational Education}

Economic, political, cultural and educational rationales have been used in discussions to the support of trans-national education. From an economic perspective, it is argued that post-industrial development depends on information as the main commodity, hence the high private and public demand for education, which makes it a prime target for trade. Since the national and international demand for higher education is high, especially in developing countries that are resource scarce, the providers of transnational education find an economic opportunity to fill the gap in spite of being advocated by UNESCO (2013), as a public good, and that knowledge should be availed - freely on the web, and by any other means. Higher education has been acknowledged to serve economic, social, cultural and political needs of nations in addition to spurring development (OECD, 2013).

The World Bank correlates higher education with economic development of emerging countries (Brenton \& Lambert, 2006). A study by the British Council predicted that 14 out of 25 countries participating in transnational education would attain more than 4\% annual economic growth between 2012 and 2014 (British Council, 2013). Further, transnational education is also regarded as cost effective (Altbach and Knight, 2007). Countries whose governments lack the financial capacity to provide higher education have permitted foreign private providers (non-profit and for-profit) to deliver specific education and training programs within their boundaries to meet the high demand (Knight, 2007; British Council, 2013; 2014).

Politically, countries have also used educational cooperation to foster international diplomacy and cooperation. This is manifested in increased recruitment of foreign students and international education advisory services. The Organization for Economic Cooperation (OECD) feels that globalization issues on economic and academic realms are essentially political choices; and universities could be the mediators between the state and the civil society, as well as the custodian of the new ethics in response to global challenges. Transnational education is seen as the cornerstone for cultural exchange- it helps to export national, cultural and moral values; increase inter-cultural knowledge, skills and research; expand social learning and development of individuals (Knight, 2007; Ziguras, 2005).

Educationally, transnational education provides for international dimension of research and teaching (Altbach and Knight, 2007); and strengthens the core structures and activities of higher learning institutions; creating sensitivities to multicultural and cosmopolitan globalization effects. It can benefit learners in cases where the national system does not; offer a different kind of program, provides higher education in minority languages, compensates for national education system. A study by the British Council (2014) indicated that $85 \%$ of transnational education students admitted that it enhances professional skills, analytical thinking (88\%), international outlook (87\%), adaptability to change (87\%), and problem solving in complex situations (85\%).

It is also argued that innovations in information and communication technologies (ICTs) have offered opportunities that can best be exploited through virtual education. There is also the prestige of studying in a foreign institution, and prospects in migrating to the nation. American immigrant policies encourage high-skilled graduates to migrate such as those in ICTs and research - though Tsiligiris (2013) argues that transnational education has the potential to combat brain drain when it is provided in the host/demand nation. Another rationale for transnational education is the growing number of mobile jobs in fields such as business, ICTs, engineering, technology and scientific research. A British Council study showed that a majority (62\%) of transnational education students believe that their earning potential is enhanced as employers (61\%) are positive to transnational education graduates (Knight, 2006; Breton, \& Lambart, 2006; British Council, 2014).

\subsection{Trends in Transnational Education: Mode of Supply and Potential of the Market}

Transnational education is supplied in three different forms- namely cross border supply, commercial presence, and presence of natural persons. Cross border supply (offshore supply) is the provision of service where the service crosses a border (This does not require the physical presence of the consumer). It comes in the form of distance 
education, e-learning and Virtual universities. It is currently a relatively small market, but with great potential, considering increased use of ICTs, especially the Internet. Commercial presence represents categories of service providers who establish commercial facilities in another country in order to render educational services. It comes in the form of local branch or satellite campuses, twinning partnerships, and franchising arrangements with local institutions. Franchising is the form of transnational education in which a higher education institution (franchiser) from a certain country grants another institution (franchisee) in another country the right to provide the franchiser's programs/qualifications in the franchisee's host country (Knight, 2007; Ziguras, 2005)).

Mostly, the franchisee only provides the first part of the programs, which is recognized as partial credits towards a qualification at the franchiser's in the context of a "program articulation"- a joint arrangement in which two or more institutions define study credits and credit transfer. In this case students enrolled in one institution have their credits recognized by the other in order to continue their studies. These may -or may not- lead to joint or double degrees. There are also large corporations and international institutions who organize their own higher education programmes which does prescribe any one educational system. They may have several branch campuses in several countries; though they are seldom recognized by the host country (Vignoli, 2004; Tsiligiris, 2013). There is growing interest and strong potential for future growth of the commercial presence mode of higher education. However, it is most controversial as it sets international rules on foreign investment.

The third mode of supply is presence of natural persons. It involves persons travelling to another country on a temporary basis or what is commonly known as staff exchange programmes to provide service - such as professors, teachers, and researchers. This mode of supply, potentially, has a strong market given the emphasis on globalization of professions and mobility of professionals (Knight, 2007). Currently, many organizations and universities are promoting this mode of supply through various mobility programmes and projects based on North-South and specific regional collaborations (See for example the German Academic Exchange Services DAAD/Dialogue on Innovative Higher Education Strategies - DIES training programmes, the Alexander Von Humbolt -AvH initiatives, www.daad.de and European Union student and staff mobility sponsored programmes. (www.europa.eu/programs/Erasmus-plus/index fr.htm)

Currently, the market for transnational education is unlimited because it operates on a free market basis. For example, in countries such as Australia and UK the export market can expand freely without cutting on the unit value of global positional goods. The English speaking countries lead in the provision of transnational education since English is the preferred language for global business and academics (Fellenson and Mahlck, 2017). There is particularly strong demand for American and British education. According to UNESCO, (2014), UK is regarded the world's $2^{\text {nd }}$ largest market (13\% of market) after the USA. Between 2012 and 2013, the annual value of transnational education to UK was 496 million pounds (UNESCO, 2014, British Council, 2016). In addition, UNESCO statistics indicate that Australia is also coming up as a major provider of global educational trade. An analysis of transnational cooperation indicates that the universities of Melbourne, Monash and Murdoch have developed into global institutions with satellite campuses in Malaysia, South Africa, Africa, London and Italy. There is a transnational capitalist alliance of 21 universities - 'universitas 21' in ten countries; including Australia, China, Canada and UK-offering on line courses with the motive of looking for the "World Best Practice" (Marginson, 2006; Currie, 2006; Ninnes, 2005).

Research shows that the leading markets for global education are the Ivy League Universities such as Harvard, Stanford and Oxford; which exercise great symbolic power as producers of the highest value of education. Their global status raises competition as they overshadow and put other universities in subordinate positions (UNESCO, 2014). The Asia - Pacific region which constitutes over half of the worlds' population (China, India, Indonesia) has potential for growth in demand for transnational education. Marginson (2006) observes that ten of the 16 world cities with over 10 million people are in the Asia Pacific region - indicating potential for increased demand for higher education. China, Thailand and Indonesia are also attractive market destinations, given the increasing demand for tertiary education by the middleclass. Latin America, Africa and Central Asia participate minimally in the global market of education; often as importers rather than exporters of the service. The knowledge and skill areas in the global market for higher education comprise of business studies, information technology, computer science, and widely spoken languages such as, English, Spanish and German as the dominating subjects (Adam, 2001; Knight, 2006).

\section{Issues in the Management of Transnational Education}

As noted, transnational education, as transnational trade in higher education, operates on cross border and mixed market systems. Therefore it is also cross cultural and cross political. Consequently, it is likely to be supplied and 
compounded in issues related to autonomy and control, qualifications and transfer of academic credits, quality assurance and accreditation, costs, commercialization and commoditization of knowledge, brain drain, competition, some forms of discrimination, including apartheid and cultural imperialism.

\subsection{Issue of Qualifications and Transfer of Academic Credits}

The wide spread of cross border deliveries of higher education has faced the difficulty of comparing quality on account of different education systems and practices. Given that the frameworks on determining qualifications are based on different benchmarks (Mayer, et al. 2011), it is difficult to determine the transferability of academic credits. The regulatory framework to deal with the diverse providers is insufficient, as governments lack the capacity to license, regulate and monitor both private and foreign higher education providers, to make sure they operate within national policy objectives and structures. Nonetheless, some of these providers operate on the basis of the home country structures, which are oftentimes considered more superior and efficient relative to those in the host country. The likely solution to this, as has been suggested and practiced elsewhere, such as through the Bologna process, is cooperation between and among nations, to harmonize domestic/regulatory frameworks with international frameworks (Knight, 2006), standardization and harmonization of practices within the context of local practices and domestic regulatory frameworks (Fellenson and Mahlck, 2017).

\subsection{Quality Assurance, Accreditation and Recognition}

It is vital for transnational education to be provided due to its positive externalities. However, this requires regulating the global space of higher education to ensure quality of delivery and practices for international accreditation and recognition (Breton, 2006). A major hindrance to this is that nations lack the capacity and perhaps the will, to address accreditation and quality assessment procedures for academic programs of new private and foreign providers (Fellenson and Mahlck, 2017). According to findings from the British Council (2013), India, Nepal, Sri Lanka and Turkey host foreign institutions without any formal regulatory structure. The research revealed that ten host countries did not have consistent and extensive data on the operations of the foreign institutions. The same report indicates that the processes of achieving accreditation were vague (in Nigeria and China) and restrictive (in Vietnam). National quality assurance systems are not only challenged by the complexities of the international education environment, but at times run parallel. For example, in federations in Canada and Germany, certain conditions that require all providers of transnational education, domestic and foreign, be subjected to the same processes and procedures are not honored. Questions of cross border recognition emerge, even when an institution (franchiser) is locally recognized and accredited, and whether such recognition is transferable to institutions (franchisees) set up outside the mother country. (Rauhvargers, 2004; Vignoli, 2004).

While program articulation will always be recognized, franchised institutions, branch campuses, offshore institutions and distance learning will some times be recognized and non- official, international institutions, corporate universities and virtual universities will almost never be recognized. There is no possibility for recognition in cases where there are no legal/normative instruments and no "good practice" has been developed in dealing with transnational education (Rauhvargers, 2004; Vignoli, 2004). A situation where legal/normative instruments exist without implementation procedures could result into a legal framework which is relatively restrictive. This might have a bearing on the quality of service provision, especially, the content of academic programmes and general practices and violation of intellectual property rights. According to Knight (2006) commercialization and commoditization of knowledge production potentially threatens research and scholarly works. Measures taken to streamline quality are, in some cases, too rigid and compromise the national autonomy over its own higher education- when nations are turned into watchdogs- by strict external audits and evaluations and when individual institutions want increased autonomy from government regulations (Knight, 2006; Cloete \&Maassen, 2007).

\subsection{The Question on Access and Escalated Costs}

While on one hand liberalized higher education opens access to the highly demanded higher education, on the other hand it exposes it for highly commercialized purposes, in terms of escalated costs, thereby threatening the nature of educational provision as a public good (Knight, 2006). Knight (2006) further casts doubt on the ability of foreign education providers would quench the thirst for higher education in countries with limited access, and whether the governments would give the providers the same grants, subsidies and tax incentives given to public providers under the national treatment obligations of General Agreement on Trade in Services (GATS). If this were to happen, Knight (2006) sees a problem of public funds spreading too thinly between domestic and foreign providers. One ethical concern is that, the international trade in education seems to favour countries with the capacity for export. Even though UNESCO endeavors that mobility of courseware does not cause money to flow from poor countries to rich countries, this incidentally is often the case (Knight, 2006; Breton, 2006) even contrary to the discussions 
underscored during, for example, the education conference of African Ministers of Education held in Addis Ababa in 1961 (UNESCO, 1961).

\subsection{Commercialization of Knowledge}

Recent trends in the management and provision of higher education have focused on the corporate and entrepreneurial model (Weber, 2005; Bosire, 2015). Trade - Related Aspects of Intellectual Property Rights agreements on research and scholarly work have the potential of commercializing and commoditization of knowledge production. This has been seen in the over emphasis of commercialization of research and knowledge dissemination, at the expense of the traditional role of university - teaching, research and service. In addition, a commercial approach to higher education has the potential of jeopardizing the academic relations of countries and institutions, by undermining training/programs (student exchange, internships) which are not associated with direct financial benefits, but have spinoff and ripple effects on research, curriculum development, teaching for partners and intercultural exchange. Although it is generally agreeable that bilateral and multilateral education agreements automatically enhance rather than jeopardize research, curriculum development and other academic aspects, for as long as the thrust in the trade concept dominates, the educational rationales for higher such education such as social, cultural and scientific developments could be compromised (Tan \& Mok, 2004; Knight, 2007).

\subsection{Competition, Apartheid and Cultural Imperialism}

Marginson (2006) observes that the global market for education is largely uneven and asymmetrical between nations, with the English speaking countries dominating. Consequently, countries with relatively higher capacity for provision of higher education have tended to 'scramble' to provide this education in countries perceived to suffer scarcities (Mohamedbhai, 2006). This situation has been perceived as a threat to some of the institutions in the receiving countries. While some have "asked government protection from the 'foreign invaders', and some governments have responded by imposing a moratorium on new distance education" (Mohamedbhai, 2006:170), others have responded by accommodation and competition as in a competitively global market. For example one South African institution was granted a contract, against competition from British institutions, to offer distance health education programs in Turkey and Israel. Still, other institutions respond by forming partnerships with the private and foreign providers; adopting an entrepreneur approach (the European Consortia of Innovative Universities- ECIU). Those with financial constraints have opted to open their borders to global foreign providers (Mohamedbhai, 2006).

Global apartheid is felt as the universities in the North dominate the platform for global knowledge production. During a World Summit on Sustainable Development (WSSD) Mbeki, then President of the Republic of South Africa, in his address to a crowd of protesters remarked and made reference to global apartheid as the greatest enemy to development (Moja, 2006). Elements of segregation are evident in international organizations' treatment of education. For instance, EOCD is keener in fostering partnership and funding of higher education in China-the world's fastest growing economy than in Africa and South America. This sentiment confirms the fear that Transnational Education could be a fertile ground for reviving colonialism and imperialism (Tarc, et. al. 2012) in the relationship between the resource rich North and resource poor South. One of the likely implications is that the North, which is favoured in the supply of Transnational Education, will likely use its comparative advantage to spread its ideologies and cultures to the South.

The issue of hybridization and fusion of cultures (acculturation) through cross border supply of education is a major concern; particularly, the argument that there is growing lack of sensitivity to the cultural bias of exported education, and the greater risk of undermining certain indigenous cultures and compromising the very spirit of internalization (Knight, 2006; British Council, 2013; Tsiligiris, 2014). There are concerns over partnerships that could perpetuate inequalities and discriminations between institutions and students in the same institution. For instance, in a partnership on teaching Political Science between Tufts and Makerere Universities, poor students who could not afford technological equipment got short changed and disadvantaged in the programme (Mohamedbhai, 2006). A similar scenario presented in the twining (transnational) programme between Egerton University, Kenya and the Massachusetts Institute of Technology and Western Michigan University, USA, where students from poor family backgrounds could not meet the programmes tuition cost requirements.

\subsection{Theoretical Challenges}

A theory is a synthesis of knowledge accumulated in a given field, often represented in symbols, diagrams, or models which assume authority as more and more scholars and researchers find it useful. The usefulness of a theory depends on how well it helps in describing, explaining, predicting and offering guidance in understanding a given 
phenomenon. As Petrella (2006) argues, there are theoretical confusions surrounding globalization agenda on transnational education. Theoretical weaknesses are realized in the non-critical approaches and humanization (social regulation) of knowledge - that is the susceptibility of academics to the demands and ideas of the dominant political world (Bosire, 2015). The theses on information and communication society are scientifically weak, hence a weak theoretical foundation for transnational education. If modernization theory that seems to be driving transnational education were to be adopted, then the whole binary and logic that "developing" countries need to leap frog to the standards of the developed countries (Ninnes, 2005) is illogical since the developed countries themselves did not "leap frog" to where they are today. (Petrella, 2006; Weber, 2005).

\subsection{Pedagogical Issues in Trans-national Education}

Alexander (2006: 724; 725) defines pedagogy as "the discourse which attends the act of teaching" (...) combines the act of teaching and its attendant discourses". He clarifies that in all practical sense, teaching is not the same as pedagogy, because teaching is both a practical and an observable act. Pedagogy covers "that act with the purposes, values, ideas, assumptions, theories and beliefs which inform, shape, and seek to justify it" (Alexander, 2006: 724). The teaching act comprises of activities, interactions and judgments which are framed by space, student organization, time and curriculum, and by routines, rules and rituals- it actually makes teaching a cultural activity. The class processes and procedures are closely related to greater questions of culture, region, agency, policy, and power control (Alexander, 2006; 2009). Different pedagogies practiced by different educational systems may create issues and problems in the management and practice of transnational education.

\subsection{Confusion Arising from Pedagogical Differences}

Alexander (2006) analysed and compared pedagogical practices of five countries and identified six prevailing constellations of teaching as follows; (1) teaching as transmission (2) teaching as induction (3) teaching as facilitation (4) teaching as negotiation (5) teaching as acceleration (6) teaching as a technology. In teaching as transmission model, the teachers see their role as passing of information to the learners. This model is predominantly practiced in many education systems globally (Sharples, et. al. 2013). Teaching as induction treats knowledge as a cultural good; its methods are expository, recitations, and argumentative talk by the learners. The French education system was the most inductive among the five countries studied. Teaching as negotiation represents a democratic pedagogy in which the child is an active agent in his/her learning, and the classroom a workshop or a laboratory. The study revealed that the model was best practiced in the USA, most likely due to the influence of the Dewey School of thought (1859-1952).

Teaching as facilitation advances the principle that children have their own way of thinking, seeing and feeling. As observed by Alexander (2006), it is based on the ideas of some early scholars, such as Piaget, who posited that children go through the same developmental processes though at different rates; and Rousseau and Froebel who advocated that learners should not be pushed but be let to learn at their own pace when they feel ready - while the teachers' role is facilitative and not directing learning (Sharples, et. al. 2013). The United States and England demonstrate a predominant use of this pedagogical approach.

Alexander (2006: 726) asserts that teaching as acceleration derives from Vygotskys' famous maxim that "the only good teaching is the one which outpaces development". This model is diametrically opposed to the principle of readiness. It aims at capturing the momentum of a lesson and driving it foreword; it requires a proper balance between the cognitive and interactive (cultural) dimensions to teaching and learning. Finally, teaching as a technology is guided by the principles of structure, economy, conciseness, and rapidity, and implemented through standardized procedures and materials. This model of pedagogy is common in Eastern and Central Europe, Bohemia, Germany and Russia.

This comparative analysis reveal different pedagogical approaches and practices between countries that may hinder effective management and practice of transnational education. For instance, Indian/ Asian students who study in an American university are likely to encounter pedagogical difficulties because the American democratic pedagogy is antithesis to the Indian pedagogy of transmission. Likewise, the Indian/ Asian students who study in a university in France may not cope with the required disputations, since their style is passive. Students from the Asian and African cultures, in particular, are more used to the lecture style of teaching, and may be uncomfortable with online interactions and learning styles of many Western universities. Students from cultures which emphasize passive learning and respect for authority may not have the skills to engage in independent, self-directed learning, and critical/analytical thinking required by Western education systems. In addition, assessment mechanisms of the Western cultures discriminate against the preferred learning styles of international students (Singh, \& Parlo, 2005; Alexander, 2006; 2009). The different pedagogical encounters of students taking a foreign education can lead to the 
psychosocial dynamics inherent to the "shock" of cultural differences (Tarc, et. al, 2012) as demonstrated in Singh and Doherty's (2005) study on "How the West is Done".

\subsection{The Dominant Language of Instruction}

Countries that practice transnational education experience the use of a dominant language in the host country that is different from that used in the mother country of the students. English is the dominant language of instruction in most universities that offer transnational education. This implies therefore, that transnational partnerships and off shore delivery of quality education can be problematic and challenging (Ziguras, 2007; Tsiligiris, 2012; 2014). For example, foreign students admitted to universities in Germany may require a one year of their studies dedicated to learning and using the German language. A similar situation is pointed out for those students admitted in universities in Russia, where the students must learn the Russian language. In such case, Tsiligiris (2012) reasons that, neither the instructors nor the students in host countries "have the ability to perform at their full capacity as teachers and learners respectively using English" (or the foreign language of instruction). In other words, the use of English, or any other foreign language) may hinder the teaching and learning experiences and not reassure quality and comparability as often suggested by the awarding institution. Tsiligiris (2012) and Morris (2005) point out the irony of internalization without use of other languages of the world in higher education, and that transnational education distorts national cultures, (erodes diversity) and promotes homogenisation towards a globalised society.

\subsection{The Effect of Transactional Distance on Learning Outcomes}

Since transnational education is mostly through e-learning, the transactional distance that is created in the encoding, decoding, reception and noise is a great concern. According to Moore (2008) transactional distance is positively related to the size of the learning group, familiarity of language and dialects, and the qualities of the medium through which the signal is transmitted. These include issues of noise, speed, and lag. A textbook and study guide with only internal dialogue would be considered to have a high transactional distance. A synchronous discussion carried out by audio conferencing would be lower (Martindale, 2002). The issue that arises from this is the effect of the amount of transactional distance on learning outcomes.

\subsection{Questions on Learners' Autonomy and Mutual Respect}

In technologically enhanced learning, the instructor's role which is usually technical, managerial, social, and pedagogical, may promote a greater intensity of control. This, combined with the rigidity of programs violates the learner's autonomy; thereby contradicting the flexibility always assumed in distance and on-line education. Violation of the learners' autonomy further interferes with the principle of mutual respect-with regard to 'privacy' of the student. The main concern here is, how can discipline be maintained? How can abuses and poor teaching be controlled? And what assurances are there of the learner's individual abilities, or even adoption of group discussions and a delivery techniques by the students? (Sherry, 1996; Cormier, 2008).

A study by Kanuka, Collet and Caswell (2002) revealed that before teaching an online course the faculties are more concerned with the structural and dialogic issues such as technological operations and creating collegial relationships; the later being more challenging. In this study the faculty confessed that they were beginning to see the students as email addresses or "little red flags" rather than people, and they missed seeing the physical features, paralinguistic cues, and other types of changes that people make over a semester. Instructors reported difficulty in knowing when to give feedback to the group and when to give it individually by e-mail. As observed by Kanuka, Collet and Caswell (2002) separation of learners and teachers can negatively affect the teaching and learning interaction, because it creates psychological and communication spaces that can potentially lead to misunderstanding between the inputs of instructors and those of the learners.

\subsection{Emerging Curriculum Issues}

Among the curriculum issues noted is the question on the content of the curriculum; specifically, how to integrate the local curriculum, such that the knowledge from the host country is accommodated. The danger in selling education outside the frontiers of a country is the attempt to impose same standards everywhere and dissociate education from the social, cultural and political origins of a country (Ziguras, 2005). Such de-contextualized 'globalized' curricula, which only reflects the context of the curriculum developer, inhibits genuine participation of the students in the context of their individual and national expectations; fails to recognize their prior skills, community knowledge, understanding, and experiences they bring into the classroom (Moris, 2005; Ninnes, 2005). There are fears that the seemingly highly skilled graduates do not necessarily address the local skill gap. However, if programs are to be adapted to the needs of the host country, will they still be the same degrees/qualifications as in the sending country? (Rauhvargers, 2004; British Council, 2014). Lecturers also get challenged on how to design a course so that the 
material engages students' prior knowledge and their skills (from diverse backgrounds), and on whether the intent should be to build on that knowledge, interrogate it, or situate new ways of thinking; yet, observing student differences provides valuable clarity for both students and instructors; and enriches the teaching and learning experiences (Tarc, et al, 2012).

Another concern is that attempts to orient the curriculum to the imperatives of globalization, often centers on Euro-American (Western) culture, "whose Eurocentric views, images and perceptions for centuries considered it to be at the worlds' centre" (Singh, 2006: 124). Progressive minded scholars and critics are of the opinion that globalization agenda for education should promote local knowledge and identities. They shun the current domineering of knowledge networks by Euro-American symbols, cultures and linguistics. Singh (2006: 124) proposes that "in order to replace the Euro-American forms of global/national history, it is strategically important to engage majority world interpretations and analyses on equal bases", especially since knowledge has become globalized (Petrella, 2006).

While it is the responsibility of full-time members of faculty, grounded in the body of knowledge in a particular discipline, to draw up the curriculum for the specific courses, some of the universities exporting higher education have relegated the assignment to adjunct lecturers. This often leads to lack of coherence and deficiency in the course design and development; and further discrepancies between the main campus curriculum and those of satellite campuses (Swenson, 2006). The problem is compounded, especially when the outsourcing of content is between educational providers and technological companies; and when the course design and content development is separated from the process of testing and assessment (Currie, 2006). The academic staff are also concerned that squeezing programs into modules or unit standard methodology, and the construction of qualifications from multiple units of learning, are inappropriate foundations for certain academic programmes (Ensor, 2007). This is so because the curriculum of professional units, or specific subjects is built on a systematic advancement of content and experiences from one level to another, through vertical and horizontal integration, for a wholesome understanding of the pertinent principles and concepts that constitute the study area or discipline (Currie, 2006; Amimo, Bosire and Role, 2014).

\section{Future Prospects for Transnational Education}

As a result of the many issues that have been raised in the management and practice of transnational education, a set of regulations have been formulated at regional and national levels to enhance good practice. Examples are the UNESCO/Council of Europe that developed a code for good practice for provision of transnational education, and Good Practice in Transnational Education Guide developed for New Zealand. Similarly, in East Africa, the Interuniversity Council for East Africa (IUCEA) has developed guidelines on standards on the management of university education in universities in the East African countries (IUCEA, 2010). Part of the standards give guidelines on the provision of transnational education for universities in East Africa. Among other standards, the guidelines point out some important requirements such as; having a written agreement between transnational education partners, ensuring equivalence in curriculum, teaching materials and assessment, adhere to specific requirements of national legislation; recognize the cultures and customs of both countries, and embed the curriculum in context - so that students can reflect on the similarities and differences of experiences at global, regional, national and local context.

For effective management, transnational education should be considered as part of a well thought out international business development strategy, rather than a peripheral activity (Ziguras, 2007; Tsiligiris, 2014). The providing institutions should dedicate resources to supporting the future development and transformation of its transnational educational structures and operations in response to market cycle demands, especially capacity building efforts in host countries. Further, higher education institutions should set up bilingual programs embedded in a real international dimension.

Recognition of certification can be enhanced by the systematic use of the Diploma Supplement (DS) developed as an initiative of the European Commission, the Council of Europe and UNESCO/CEPES (Vignoli, 2004; Ninnes, 2005; Tsiligiris, 2014). Regulation difficulties can be solved by use of regional regulation frameworks, though this may injure the autonomy of national educational systems. Vignoli (2004) has particularly noted that countries with more open regulatory frame works such as Austria, Netherlands and Norway have fewer problems with implementation of transnational education systems because they tend to absorb non official higher education by formalizing it as it emerges.

According to Vignoli (2004), the quality of franchised programs/qualification can be enhanced by integrating the programs/qualification in the official system of the awarding country. In this case, the exported program must be recognized in the original country. Similarly, offshore and international institutions can have their courses 
legitimized through alliances with well established institutions. Label quality can be obtained by acquiring international accreditation by private agencies in thematic areas. All these measures should be done with some flexibility because rigid control may be in conflict with the regional or international laws. A better approach would be to create mechanisms or incentives which encourage transnational institutions to submit to the quality assurance procedures that apply to official higher education in the host country (Vignoli, 2004).

To strengthen the theoretical foundation for transnational education, particularly the pedagogical aspects, several theories have been suggested, namely - the theory of social reconstruction, Paulo Freire's pedagogy of the oppressed, Holmbergs theory of teaching distance education, Kegaans' theory of integrating teaching and learning, Garrisons' theory of communication and learner control and Moores' transactional theory (Garrison, 2000; Ramdoo, 2008; Bernath, \& Vidal, 2006). When applied, these theories are likely to influence practice so for a more effective implementation of transnational education. Scholars differ on which theory would be more effective and relevant to pedagogical management of transnational education. The theory of social reconstruction seems appropriate for innovative curricula and pedagogical strategies that contribute towards construction of a new consciousness of collective international social cooperation. However, some educators such as Freire argue that it is the pedagogy of the oppressed that will help to arouse the consciousness necessary for social reconstruction to enable the development of a more appropriate curriculum (Garrison, 2000).

This notwithstanding, transactional theory seems to get more acceptance in recent research - the argument being that it logically in-cooperates the concepts and the physical attributes that describe the use of electronics in e-learning, blended learning, and wired/wireless telecommunication in online learning and distance education. Out of the 93 authorities cited at 17 conferences of the International Council for Distance Education, 1938-1995, the theory of transactional education was third in position. The chapter on transactional distance in Keegan's theoretical principles of distance education is the second most widely cited item. In spite of this much support, the only argument critics against is that transactional theory is too descriptive (Moore, 2008; Ramdoo, 2008).

To solve and contain the pedagogical issues raised, instructors are advised to embrace techno- social pedagogies using technology for knowledge and cultural reproduction and teaching students the right terms, symbols and routines required to interact with technology (Jon, 2004; Brown, 2006; Moore, 2008). In response to disjunctive national/global flows, Singh (2005) suggests that there should be "vital learnings" across the curriculum to enable students to take advantage of the historical, ideological, and localizing practices of globalization-producing worthwhile knowledge from the prospects there in. Breton and Lambart (2006), Singh (2005) and Ninnes (2005) suggest that for globalization to benefit all, there is need to share growth in a more equitable manner through establishment of Global Development Learning Networks.

\section{Conclusion}

Transnational education has received attention lately due to interests expressed by the supplying countries and students from regions that demand this type of educational service. Other than for business interests by the host countries, transnational education has provided capacity enabling opportunities for nations that receive the service. In addition, it has also enabled the transfer of cultures, experiences and generally tended towards equalization and globalization of knowledge at the local level.

However, the manner in which transnational education is provided is provoking more debates, interests and questions than clear cut answers about its impact and implications for higher education. The debates come from a wide range of issues focusing on its guiding philosophical foundations, management, pedagogy and, curriculum design and prescriptions. Questions on these aspects have only generated a few responses from scholars across the globe.

A major concern is lack of awareness on the operations of transnational education providers in the host countries, existence of scanty data found in host countries; meaning that quality can easily be compromised if there are no quality audits. While the quality issues have received a lot of attention, pedagogical and curriculum issues have not been fully exhausted in past research and scholarship. It is recommended that Educational policy makers, researchers and senior university managers and administrators, work in collaboration with government, non-governmental organizations and the General Agreement on Trade in Services (GATS) to discuss the various issues raised in view of informing the future direction in the provision of transnational education.

\section{References}

Adam, S. (2001). Transnational Education project: Report and recommendations. Presented at Confederation of European Union Rectors Conferences. 
Alexander, R. (2009). Towards a comparative pedagogy. In Cowen, R. and Kazamias, A.M (ed). International Handbook of Comparative Education, Springer, 923-942. https://doi.org/10.1007/978-1-4020-6403-6_59

Alexander, R.J. (2006). 'Dichotomous pedagogies and the promise of cross--cultural comparison'. In Halsey, A.H., Brown, P., Lauder, H. and Dilabough, J. (ed) Education: Globalisation and Social Change, Oxford: Oxford University Press, 722-733.

Altbach, P.G \& Knight, J. (2007). The internationalization of higher education: Motivation and Realities. Journal of Studies in International Education, 11(3-4), 290 - 305. https://doi.org/10.1177/1028315307303542

Amimo, C., Bosire, J., Role, E. (2014). Theoretical underpinnings of curriculum change in developing countries: Is complexity theory the new wine in Lewin's wineskin. International Journal of Academic Research in Progressive Education and Development, 3(3), 38 - 49. https://doi.org/10.6007/IJARPED/v3-i3/950

Bernath, U. \& Vidal, M. (2006). The Theories and the Theorists: Why Theory is Important for Research. From http://www.eden-online.org/contents/conferences/research/barcelona/D_S-Holmberg-Moore-Peters-Oct06.pdf

Brenton, G. \& Lambert, M. (2006). Universities and globalization: Private linkages, public trust. Geneva: UNESCO.

Breton, G. (2006). Higher education: From internalization to globalization. In Brenton, G. and Lambert, M. (2006). Universities and Globalization. Geneva: UNESCO. p. 1-30.

British Council. (2013). The evolution of transnational education: data, definitions, opportunities and impacts analysis. Retrieved

from http://www.britishcouncil.org/sites/britishcouncil.uk2/files/the_shape_of_things_to_come_2.pdf

British Council. (2014). The impact of transnational education on host countries, academic, cultural, economic and skills impacts and implications of programme and provider mobility. [Online] Available: https://www.daad.de/medien/hochschulen/projekte/studienangebote/2014_e003_tne_stud y_final_web.pdf

British Council. (2016). The scale and scope of UK Higher Education Transnational Education. London: The British Council.

Brown, A.D. (2006). A narrative approach to collective identities. Journal of Management Studies, 43(4), 731-753. https://doi.org/10.1111/j.1467-6486.2006.00609.x

Bosire, J.N. (2015). Management of the University Curriculum in a Rapidly Changing Environment. Challenges and Prospects. International Journal of Academic Research and Review, 3(2).

Cloete, N., Maassen, P. (2007). Global reform trends in higher education. In Cloete, N., Maassen, P., Fehnel, R.,Moja, T., Gibbon, T., and Perold, H. (2007). Transformation in higher education: Global pressures and local realities pp. 7-34.

Cormier, D. (2008). Rhizomatic education: Community as curriculum. Journal of Online $\quad$ Education, 4(5).

Currie, J. (2006). Australian universities as enterprise universities: Transformed players on global stage. In Brenton, G. \& Lambert, M. (2006). Universities and globalization: Private linkages, public trust. Quebec, Canada; UNESCO, 179-194.

Ensor, P. (2007). Curriculum. In Cloete, N., Maassen, P, Fehnel,R,. Moja, T, Gibbon, T. \& Perold, H. Transformational change in higher education: Global pressures and local realities. Netherlands: Springer; pp. 179-193.

Fellenson, M.\& Mahlck, P. (2017). Untapped research capacities? Mobility and collaborationat the intersection of international development aid and global science regimes. International journal of African higher education, $4(1), 1-13$.

Garrison, R. (2000). Theoretical challenges for distance education in the 21st century: Ashift from structural to transactional issues. The International Review of Research in Open and Distance Learning, 1(1). https://doi.org/10.19173/irrodl.v1i1.2

Inter University Council for East Africa. (2010). A Road Map to Quality: Handbook for Quality Assurance in Higher |Education, Volume 1: Guidelines for Self -Assessment at Programme Level. Kampala: IUCEA.

Jon, D. (2004). A loophole in Moore's law of transactional distance, icalt, 41-45, Fourth IEEE International Conference on Advanced Learning Technologies (ICALT'04), 2004 retrieved on $6^{\text {th }}$ December, 2009 from http://www.computer.org/portal/web/csdl/doi/10.1109/ICALT.2004.1357371 
Kanuka, H., Collet, D., \& Caswell, C. (2002). University instructor perceptions of the use of asynchronous text-based discussion in distance courses. American journal of distance education, 16(3), 151 - 165. https://doi.org/10.1207/S15389286AJDE1603_3

Knight, J. (2007). Higher Education and trade agreements: What are the policy implications? In Breton, $\mathrm{G}$ and Lambart, M. (2006) , Universities and Globalization; Private linkages, public trust, Canada. UNESCO. 81-105.

Marginson, S. (2006). National and global competition in higher education. In Lauder, H., Brown, P., Dillabough, A. \& Halsey A. (2006) Education, Globalization \&Social Change New York: Oxford University Press. https://doi.org/10.1007/s10734-004-7649-x

Martindale, N. (2002). The cycle of oppression and distance education. Athabasca University, February 2002.

Mayer, P., Wilde, M.,Dinku, A., Fedrowitz, J., Shitemi, N., Wahlers, M., Ziegele, F. (Eds).(2011). Challenges for faculty management of higher education institutions. Osnabruck: University of Applied Sciences, Osnabruck.

Mohamedbhai, G. (2006). Globalization and its implications for universities in developing countries. In Brenton, G and Lambert, M. Universities and Globalization: Private linkages, public trust. Paris: UNESCO

Moja, T. (2006). Globalization apartheid: The role of higher education in development. In Breton, G and Lambart, M. (2006), Universities and Globalization; Private linkages, public trust, Canada.UNESCO. 163-175.

Moore, M., G. (2008). The theory of transactional distance. In M. G. Moore (Ed.), Handbook of Distance education (2nd Ed., pp. 89-105). Mahwah, NJ: Lawrence Erlbaum Associates.

Morris, G. (2005). Performing pedagogy and (re) construction of global selves: Performing pedagogy and the (re) construction of global/local selves. In Apple, M., W.,Kenway, J., \& Singh, M. (2006). Globalizing education: Policies, pedagogies and politics. New York: NY. Lang publishing, Inc, pp. 135-149.

Ninnes, P. (2005). Higher education engaging with the "developing' world: The case of the virtual colombo plan. In Ninnes, P., \& Hellsten, M. Internationalizing higher education. Critical explorations of pedagogy and policy pp. 141-158. Hong Kong, Springer. https://doi.org/10.1007/1-4020-3784-8_8

OECD. (2013). Assessment of higher education learning outcomes feasibility study report: Volume 2 - data analysis and national experiences. OECD.

Petrella, R. (2006). The global knowledge wall. Universities and globalization: Private linkages, public trust. Canada. UNESCO. 127-135.

Ramdoo, G. S. (2008). Beyond the theoretical impasee: Extending the applications of transactional distance theory. Retrieved from http://www.irrodl.org/index.php/irrodl/article/view/541/1148

Raughvargers, A. (2004). Definitions and Code of Good practice based on the results of Council of Europe/UNESCO working group on Transnational Education. Retrieved from www.ehea.info/uploads/seminars/trans_edu. (1).pdf.

Sharples, M., McAndrew, P., Weller, M., Ferguson, R., FitzGerald, E., Hirst, T., \& Gaved, M. (2013). Innovating Pedagogy 2013: Open University Innovation Report 2. Milton Keynes: The Open University, Institute of Educational Technology, The Open University, Walton Hall, Milton Keynes, MK7 6AA United Kingdom.

Sherry, L. (1996). Issues in distance learning. International learning of educational Telecommunication, 1(4), 337 365 .

Singh, M. (2005). Responsive education: Enabling transformative engagements with transitions in global/national imperatives. In Apple, M., W., Kenway, J.,\& Singh, M. (2006). Globalizing education: Policies, pedagogies and politics. New York: NY. Lang publishing, Inc., pp.113-134.

Singh, M. (2006). Globalizing education: Policies, pedagogies and politics. New York. NY. Lang publishing, Inc.

Singh, P., \& Doherty, C. (2005). How the west is done: Simulating western pedagogy in a curriculum for Asian international students. In Ninnes, P., \& Hellsten, M. Internationalizing higher education critical explorations of pedagogy and policy, pp. 53-73. Hong Kong, Springer. pp. 53-73

Swenson, C. (2006). New models for higher education creating an adult-centred institution. In Brenton, G. \& Lambert, M. (2006). Universities and globalization: Private Linkages, public trust. Quebec, Canada; UNESCO.

Tan, J., \& Mok, H. (2004). Globalization and Marketization in education: A comparative analysis of Hong Kong and Singapore. Cheltenham, UK: Edward Elgar. 
Tarc, P., Mishrar-tarc, A., Ng-A-Fook, N., \&Trilokekar, R.D. (2012). Reconceiving International Education:

Theorizing limits and Possibilities for transcultural learning. Canadian and International Education, 41(3), $1-20$.

Tsiligiris, V. (2012). What is wrong with internationalisation of higher education? It is the language, stupid! Anglohigher, 25 June . Retrieved from http://www.anglohigher.com/casestudies/casestudy_detail/57/39

Tsiligiris,V. (2013). Transnational higher education partnerships: overcoming higher education access barriers and "brain-drain" reversal in Greece. In: T. Gore \&M. Stiasny eds. Going global: identifying trends and drivers of international education. Emerald Group Publishing.

Tsiligiris, V. (2014). Transnational higher education vs. International student mobility substitutes or distinct markets? Observatory on Borderless Higher Education, London UK.

UNESCO. (2014). Top 20 countries for international students? UNESCO Institute of Statistics. Geneva. UNESCO

UNESCO. (2013). Media and information literacy: Policy and strategy guidelines. Geneva: UNESCO.

UNESCO. (1961). Final report of the conference of African states on the development of Education in Africa held in Addis Ababa, 15-25 May 1961. Geneva: UNESCO.

Vignoli, G. (2004). What is transnational education? Retrieved from http://www.cimea.it/files/207_114.pdf

Weber, L.E. (2005). "Nature and Scope of the Public Responsibility for Higher Education and Research". In Weber, L.E. \& S. Bergan. (Eds). The Public Responsibility for Higher Education and Research, Strasbourg: Council for Europe High Education Series No. 2. pp $13-28$.

Ziguras, C. (2005). International trade in education: Governing the liberalization and Regulation of private enterprise, pp.93-112. In Apple, M., W., Kenway, J., \& Singh, M. (2006). Globalizing education: Policies, pedagogies and politics. New York. NY. Lang publishing, Inc. pp. 93-112.

Ziguras, C. (2007). Good Practice in transnational education: A guide for New Zealand providers. Retrieved from http://mams.rmit.edu.au/b0fsg6huol3q1.pdf 